\title{
The effect of microsilica and refractory cement content on the properties of andalusite based Low Cement Castables used in aluminum casthouse
}

\section{(O efeito do teor de microsílica e de cimento refratário nas propriedades de LCCs usados em moldagem de alumínio)}

\author{
E.A. Firoozjaei ${ }^{1}$,A. Saidi ${ }^{1}$, A. Monshi ${ }^{1}$, P. Koshy ${ }^{2}$ \\ ${ }^{1}$ Isfahan University of Technology, Department of Materials Engineering, Isfahan8415683111, Iran \\ ${ }^{2}$ School of Materials Science and Engineering, University of New South Wales, Sydney NSW 2052, Australia \\ e.adabifiroozjaei@ma.iut.ac.ir
}

\begin{abstract}
The bonding system in low cement castables is achieved by the use of calcium aluminate cement, microsilica and reactive alumina. The lime/silica ratio critically impacts the liquid phase formation at high temperatures and subsequently the corrosion resistance and the mechanical and physical properties of the refractory. In the current study, the effects of microsilica and cement contents on the corrosion resistance and the physical and mechanical properties of Andalusite Low Cement Castables (LCCs) refractories were investigated. Alcoa Cup test was used to evaluate the corrosion resistance of the castables at $850{ }^{\circ} \mathrm{C}$ and $1160{ }^{\circ} \mathrm{C}$. The study showed that an increase in the microsilica/cement ratio improves the physical and mechanical properties of the castable, but at the expense of the corrosion resistance. When a fixed amount of $\mathrm{BaSO}_{4}$ was added to the base refractory material, barium celsian along with glassy phase formation was observed to increase with the increase in the microsilica/cement ratio in the refractory. The presence of the glassy phases was noted to lower the positive effect of Ba-celsian formation on improving the corrosion resistance of the refractory. The observed results were validated using thermodynamic calculations which indicated that Ba-celsian phase was more resistant than Ca-anorthite for applications involving contact with molten aluminum.

Keywords: castables, refractories, low cement castables.
\end{abstract}

\section{Resumo}

O sistema de ligantes em concretos de baixo cimento é produzido com o uso de cimento de aluminato de cálcio, microsílica e alumina reativa. A razão cálcia/sílica tem importância crucial na formação de fase líquida a altas temperaturas e posteriormente na resistência a corrosão e nas propriedades mecânicas e físicas do refratário. Neste trabalho foram investigados os efeitos do teor de microsílica e de cimento na resistência à corrosão e nas propriedades mecânicas e físicas de refratários de baixo teor de cimento Andalusita (LCC). O teste da Alcoa foi usado para avaliar a resistência à corrosão dos concretos a $850^{\circ} \mathrm{C}$ e $1160{ }^{\circ} \mathrm{C}$. O estudo mostrou que um aumento na razão microsílica/cimento melhora as propriedades mecânicas e físicas do concreto, mas às custas da resistência à corrosão. Quando um teor fixo de $\mathrm{BaSO}_{4}$ foi adicionado ao material refratário base, observou-se um aumento de barium celsian junto com a formação de uma fase vítrea com o aumento da razão microsílicalcimento no refratário. Foi observado que a presença de fases vítreas diminui o efeito positivo da formação Ba-celsian na melhora da corrosão à resistência do refratário. Os resultados observados foram validados por meio de cálculos termodinâmicos que indicaram que a fase Ba-celsian era mais resistente que a Ca-anortita para aplicações envolvendo contato com alumínio líquido.

Palavras-chave: concretos, refratários.

\section{INTRODUCTION}

Aluminosilicate based low cement castables (LCC) are widely used in the aluminum industry for the refractory linings of melting and holding furnaces and their usage has become more commonplace due to advancements in the installation techniques. Corrosion of the refractory materials during the casting process for aluminum alloys increases the overall cost of production. The selection of the appropriate refractory composition for Al-casting applications requires the comprehensive characterization of the physical, mechanical and chemical properties of the materials $[1,2]$. The bonding system in low cement castables is achieved by using calcium aluminate cement, microsilica and reactive alumina [3]. These three constituents have a strong influence on the mechanical and physical properties of the castables as well as their corrosion behavior when in contact with molten aluminum. Cement is an important constituent of the low cement castables and its content in low cement castables range from 5 to $8 \%$ [3, 4]. Calcium aluminate phases are usually a mixture of calcium monoaluminate 
(CA) and calcium dialuminate $\left(\mathrm{CA}_{2}\right)$ [5]. However, increasing the cement content also increases the amount of calcium aluminosilicates formed (anorthite and gelenite), which tends to reduce the amount of free silica, and hence improves the corrosion resistance of castables in contact with molten aluminum [6]. The lime/silica ratio critically impacts the liquid phase formation at high temperatures and thereby affects both the corrosion behaviour, and mechanical properties like hot strength and creep resistance. This ratio is also critical in establishing the amount and viscosity of the liquid phases as well as hot strength and creep resistance [7]. Cement phases are observed to be susceptible to molten metal attack and are believed to be the starting point for corrosion [8]. The higher water requirement of these castables also reduces the density and subsequently increases the porosity of the refractory matrix [9]. This issue has led to the evolution of low (LCC), ultra low (ULCC) and zero cement castables (ZCC). Low cement castables tend to contain greater quantities of fine/ultra-fine particles, thereby promoting improved densification and better mechanical properties, although they exhibit greater porosity [10]. Moreover, ceramic-bonded shaped products based on aggregates of calcium aluminate minerals, are used in aluminum industry, due to their advantageous behavior against corrosive media [11, 12].

In the last three decades, microsilica has been widely used as filler in refractory materials, particularly in castables [3]. Microsilica particles have an average size of 0.15 microns and are an amorphous form of silica which may contain smaller quantities of impurities like $\mathrm{C}$, Na or $\mathrm{K}$ formed along the production route. Of late, microsilica from ferrosilicon production is not used for refractory applications owing to higher impurity contents [13].

Microsilica in a fresh castable has a dual effect; once properly dispersed, it helps to reduce the cement content of refractory castables due to the small particle size of microsilica. Use of microsilica may also reduce the open porosity from about $20-30 \%$ to $8-16 \%$ after firing at $1000{ }^{\circ} \mathrm{C}$, and the drop in mechanical strength that is experienced in conventional castables at intermediate temperatures changes to that of a steady increase. The beneficial effects of microsilica in castables are well established both in theory and practice [3]. Microsilica is thus added to alumina based refractories to improve the mechanical properties at lower costs and its utilisation results in a two-fold increase in mechanical strength over the same composition obtained by using chemical grade silica [10]. However, microsilica is believed to improve the flow behaviour of castables through the formation of low melting liquid calcium aluminosilicate phases [7]. Thus the properties of castables containing microsilica are greatly influenced by the $\mathrm{CaO}$ content in the composition [14].

Acting as a filler is not the only effect of microsilica in refractory castables. It has been shown in studies of cement pastes with microsilica that a certain fraction of the microsilica reacts with the cement and water to form socalled C-A-S-H $\left(\mathrm{CaO}-\mathrm{Al}_{2} \mathrm{O}_{3}-\mathrm{SiO}_{2}-\mathrm{H}_{2} \mathrm{O}\right)$ phases in addition to the C-A-H $\left(\mathrm{CaO}-\mathrm{Al}_{2} \mathrm{O}_{3}-\mathrm{H}_{2} \mathrm{O}\right)$ and $\mathrm{A}-\mathrm{H}\left(\mathrm{CaO}-\mathrm{Al}_{2} \mathrm{O}_{3}\right)$ phases normally found in hydrated cement. The C-A-S-H phases are of zeolitic nature and the amounts of these hydration products are dependent on the quality (purity) of the microsilica [3].

If no other additives are present in the refractory, the amount of free silica formed from microsilica will remain unchanged, and this undergoes reduction by molten aluminum, resulting in the formation of $\alpha$-corundum within the castable. Equations A and B illustrate the corrosion of silica bearing constituents in contact with molten aluminum alloy

$4 \mathrm{Al}_{(\mathrm{L})}+3 \mathrm{SiO}_{2(\mathrm{~S})}=2 \mathrm{Al}_{2} \mathrm{O}_{3(\mathrm{~S})}+3 \mathrm{Si}_{(\mathrm{L})}$

$8 \mathrm{Al}_{(\mathrm{L})}+3\left(3 \mathrm{Al}_{2} \mathrm{O}_{3} \cdot 2 \mathrm{SiO}_{2}\right)_{(\mathrm{S})}=13 \mathrm{Al}_{2} \mathrm{O}_{3(\mathrm{~S})}+6 \mathrm{Si}_{(\mathrm{L})}$

Thus for aluminum melting application, the presence of silica is not beneficial due to its low chemical resistance to aluminum attack. The quality of microsilica determines its properties and therefore using high quality microsilica decreases the amount of water needed and also the percentage of open pores [16]. Refractory manufacturers use non-wetting agents (additives) to enhance the corrosion resistance of aluminosilicates. The most common additives are $\mathrm{BaSO}_{4}, \mathrm{CaF}_{2}$ and $\mathrm{AlF}_{3}$ [17]. Also, the addition of $\mathrm{Mg}$ and $\mathrm{Zn}$ to molten aluminum reduces the surface tension and viscosity of the molten metal, resulting in an increase in penetration of molten aluminum into refractory material pores [18]. Magnesium causes corundum development, which is the main reason of aluminosilicate refractory corrosion by molten aluminum $[19,20]$.

Andalusite is a natural aluminosilicate mineral $\left(\mathrm{Al}_{2} \mathrm{SiO}_{5}\right)$ available in grain sizes of up to 8 millimeters, and unlike calcined refractory materials such as 60 wt. $\% \mathrm{Al}_{2} \mathrm{O}_{3}$ chamotte or bauxite, an andalusite grain is a single crystal or a piece of a single crystal which contains very low quantities of fluxes $\left(\mathrm{Na}_{2} \mathrm{O}, \mathrm{K}_{2} \mathrm{O}, \mathrm{CaO}, \mathrm{MgO}\right)$ and remains intact in density and shape after firing up to $1200{ }^{\circ} \mathrm{C}$ [21]. Because of these reasons, castable refractories based on andalusite are used in this study.

The aim of this study is to evaluate the effect of microsilica and cement content on the physical, chemical and mechanical properties of andalusite LCC refractories.

\section{EXPERIMENTAL PROCEDURE}

The mineralogical composition of the base castable is given in Table I.

The chemical compositions of andalusite and microsilica are reported in Tables II and III respectively.

In this study andalusite having a particle size distribution between 0.16 to $5 \mathrm{~mm}$ was used. The raw materials used in this study were of industrial grade and were supplied by Amol Refractory Industrial Company. The contents of cement and microsilica in the refractory castables and the chemical composition of the base castable are given in 
Table I - Mineralogical Composition of base castable refractory materials.

[Tabela I - Composição mineralógica de materiais refratários de concreto.]

\begin{tabular}{ccccccccc}
\hline Material & & \multicolumn{2}{c}{ Andalusite } & & Barite & R.A & M.S and Cement & STTP \\
\hline $\begin{array}{c}\text { Size range } \\
(\mathrm{mm})\end{array}$ & $(3-5)$ & $(1-3)$ & $(0-1)$ & 0.16 & 0.04 & $<0.003$ & 0.00015 & $<0.003$ \\
Weight $\%$ & 15 & 25 & 30 & 5 & 5 & 10 & 10 & 0.1 \\
\hline (And: Andalusite, R.A: Reactive Alumina, M.S: Microsilica, Cement: calcium Cement, STPP: Tree Poly Phosphate).
\end{tabular}

Table II - Chemical composition of andalusite used in this study.

[Tabela II - Composição química da andalusita usada neste estudo.]

\begin{tabular}{ccccccccc}
\hline $\mathrm{Al}_{2} \mathrm{O}_{3}$ & $\mathrm{SiO}_{2}$ & $\mathrm{CaO}$ & $\mathrm{MgO}$ & $\mathrm{K}_{2} \mathrm{O}$ & $\mathrm{Fe}_{2} \mathrm{O}_{3}$ & $\mathrm{TiO}_{2}$ & $\mathrm{Na}_{2} \mathrm{O}$ & LOI* $^{*}$ \\
\hline 59.58 & 37.64 & 0.77 & 0.3 & 0.12 & 1.12 & 0.1 & 0.18 & 0.19 \\
\hline * LOI Loss on ignition & & &
\end{tabular}

* LOI: Loss on ignition

Table III - Chemical composition of used microsilica in this study.

[Tabela III - Composição química da microsílica usada neste estudo.]

\begin{tabular}{cccccccc}
\hline $\mathrm{Al}_{2} \mathrm{O}_{3}$ & $\mathrm{SiO}_{2}$ & $\mathrm{CaO}$ & $\mathrm{MgO}$ & $\mathrm{K}_{2} \mathrm{O}$ & $\mathrm{Fe}_{2} \mathrm{O}_{3}$ & $\mathrm{Na}_{2} \mathrm{O}$ & LOI* \\
\hline 0.3 & 94.5 & 0.28 & 0.45 & 0.5 & 0.93 & 0.1 & 2.94 \\
\hline *LOI: Loss on ignition & & & & & &
\end{tabular}

Table IV - The content of cement and microsilica in different samples.

[Tabela IV - Teor de cimento e de microsílica em diferentes amostras.]

\begin{tabular}{cl}
\hline No. of Body & Cement and Microsilica \\
\hline 1 & Microsilica 2\% - Cement Secar71 8\% \\
2 & Microsilica 3\% - Cement Secar71 7\% \\
3 & Microsilica 4\% - Cement Secar71 6\% \\
4 & Microsilica 5\% - Cement Secar71 5\% \\
5 & Microsilica 6\% - Cement Secar71 4\% \\
\hline
\end{tabular}

Table V - Chemical composition of castable refractory.

[Tabela $V$ - Composição química do concreto refratário.]

\begin{tabular}{ccccccccc}
\hline $\mathrm{Al}_{2} \mathrm{O}_{3}$ & $\mathrm{SiO}_{2}$ & $\mathrm{CaO}$ & $\mathrm{MgO}$ & $\mathrm{K}_{2} \mathrm{O}$ & $\mathrm{Fe}_{2} \mathrm{O}_{3}$ & $\mathrm{TiO}_{2}$ & $\mathrm{Na}_{2} \mathrm{O}$ & Others \\
\hline 61.46 & 31.12 & 2.77 & 0.34 & 1.23 & 0.93 & 0.2 & 0.38 & 1.5 \\
\hline
\end{tabular}

Tables IV and V, respectively.

The amount of water needed to treat the castable was 4.5$6.5 \mathrm{wt} . \%$. Increasing the microsilica content from 2 to $6 \mathrm{wt} . \%$ results in the decrease in the water required from 6.5 to 4.5 wt. $\%$. The original dry batch of materials was mixed for 4-5 min, and then mixed with water in Hobart mixer for the same time. The castable was poured in the mold and compacted by shaking. Samples were kept in the mold for $24 \mathrm{~h}$ to set completely. Then they were removed from the mold and kept for $24 \mathrm{~h}$ for aging. Samples were dried at $110{ }^{\circ} \mathrm{C}$ for another
$24 \mathrm{~h}$. Two series of samples were prepared by using two different kinds of molds. Internal dimensions of the first mold were $16 \times 4 \times 4 \mathrm{~cm}^{3}$. The samples were tested to determine the Permanent Linear Change (PLC), Cold Modulus of Rupture (CMOR), Cold Crushing Strength (CCS), Bulk Density (BD) and Apparent Porosity (AP) at temperatures of $110{ }^{\circ} \mathrm{C}, 800{ }^{\circ} \mathrm{C}, 1100{ }^{\circ} \mathrm{C}$ and $1350{ }^{\circ} \mathrm{C}$. The temperatures were chosen to simulate the different temperature regimes experienced by the material in the actual operating scenario (maximum temperature in aluminum melting furnaces does 
Table VI - Type and Standard for tests conducted on the refractories. [Tabela VI - Tipo de testes e teste padrão aplicados nos refratários.]

\begin{tabular}{lr}
\hline Type of test & Standard verification \\
\hline $\begin{array}{c}\text { CCS and } \\
\text { CMOR }\end{array}$ & $\begin{array}{r}\text { C133-97 Standard Test Methods for Cold Crushing Strength and Modulus of } \\
\text { Rupture of Refractories; ASTM Standard 2001 }\end{array}$ \\
PLC & $\begin{array}{r}\text { C133-97 Standard Test Methods for Cold Crushing Strength and Modulus } \\
\text { of Rupture of Refractories; ASTM Standard 2001 }\end{array}$ \\
BD and AP & $\begin{array}{r}\text { C20-00 Standard Test Methods for Apparent Porosity, Water Absorption, Apparent Specific Gravity, } \\
\text { and Bulk Density of Burned Refractory Brick and Shapes by Boiling Water; ASTM Standard 2001 }\end{array}$ \\
\hline
\end{tabular}

not exceed $1350{ }^{\circ} \mathrm{C}$ while the minimum temperature is nearly $700{ }^{\circ} \mathrm{C}$ ). Therefore the determination of the properties of the castable at these temperatures can help in understanding the performance of this castable in aluminum melting furnaces. Internal dimensions of the cylindrical mold (second mold) were $6 \mathrm{~cm}$ in diameter and $5.5 \mathrm{~cm}$ in height. After firing the cylindrical samples at $950{ }^{\circ} \mathrm{C}$ and $1100{ }^{\circ} \mathrm{C}$ for $5 \mathrm{~h}$, they were drilled to prepare the cavity for molten aluminum. The cavity was $3 \mathrm{~cm}$ in diameter and $4 \mathrm{~cm}$ in depth (internal dimensions). Same amount of aluminum alloy (about $2 / 3$ of the height) was melted in the crucible (cylindrical samples). Static corrosion tests were applied for $150 \mathrm{~h}$ at $850{ }^{\circ} \mathrm{C}$ and $72 \mathrm{~h}$ at $1160{ }^{\circ} \mathrm{C}$. The aluminum alloy contained 5\% Mg and 5\% $\mathrm{Zn}$. Presence of these elements makes this alloy more corrosive. After corrosion tests, the crucibles were sectioned using a masonry saw and the penetration reaction was studied. Appropriate sections of the penetrated area were chosen and mounted in epoxy resin for microscopic analysis (OM and EDS). Microstructure of the samples was examined by optical microscopy $(\mathrm{OM})$ and Scanning electron microscopy (SEM (EDS): Cambridge Cam Scan MV2300). For X-ray diffraction (XRD) the heat treated samples were crushed and sieved $<100 \mathrm{~mm}$ and the spectra were recorded using Philips: X-PERT-MPD operating at 30 $\mathrm{mA}$ and $40 \mathrm{kV}$, using Ni-filtered $\mathrm{Cu}$ Ka radiation. The type of tests used and their standards are detailed in Table VI.

\section{RESULTS AND DISCUSSION}

Effect of microsilica/cement ratio on Permanent Linear Change (PLC)

Fig. 1 shows the variation of PLC versus microsilica content at different temperatures.

It can be seen that the PLC at $110{ }^{\circ} \mathrm{C}$ was nearly zero while linear expansion was observed in almost all bodies at all other temperatures. Andalusite has been known to display considerable expansion on heating [18] and thus the expansion at these higher temperatures can be attributed to andalusite. From Fig. 1, it is clear that the rate of PLC increment increases with the microsilica content. The PLC variations at $800{ }^{\circ} \mathrm{C}$ and $1100{ }^{\circ} \mathrm{C}$ are negligible while it

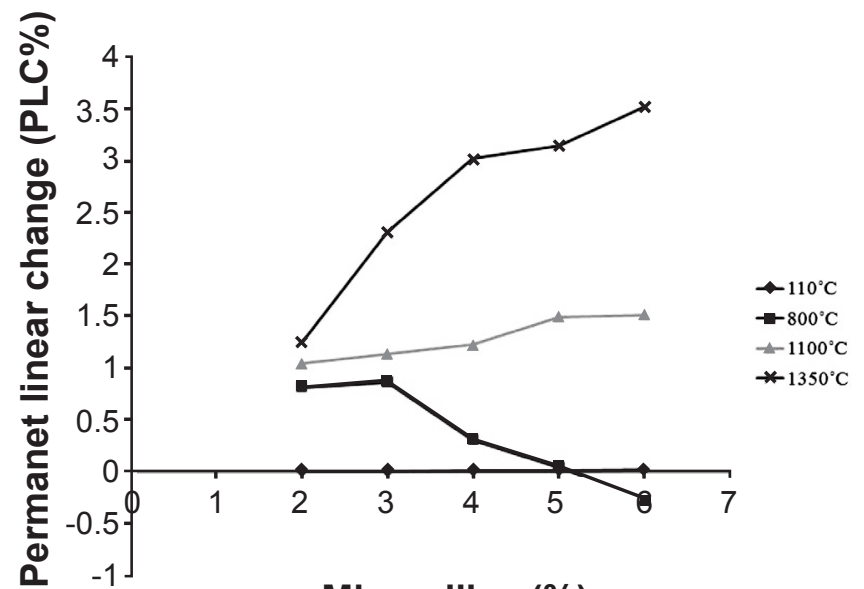

Microsilica (\%)

Figure 1: Effect of microsilica and cement content on PLC (as microsilica content increases from 2 to $6 \mathrm{wt} . \%$, cement content decreases from 8 to 4 wt.\%).

[Figura 1: Efeito do teor de microsílica e de cimento na variação linear permanente (PLC) (com o aumento do teor de microsílica de 2 a 6 peso\%, o teor de cimento diminui de 8 para 4 peso\%).]

is quite high at $1350{ }^{\circ} \mathrm{C}$. At temperatures above $1280{ }^{\circ} \mathrm{C}$, andalusite yields $80 \%$ mullite and $20 \%$ silica glassy phase [22]. A volumetric distribution calculation presents that for the large grains of andalusite, the overall volume expansion due to mullitization is $\sim 4.5 \%$. The volumetric variation of the crystal phases alone, i.e. andalusite to mullite crystals, is $-18 \%$, while the glass volume variation is $+22 \%$ (bulk densities of silica glass, andalusite and mullite are 2.2-2.6, 3.15 and $3.2 \mathrm{~g} / \mathrm{cm}^{3}$, respectively) [23]. The differences in the densities cause expansion at higher temperatures $\left(1350{ }^{\circ} \mathrm{C}\right)$. Furthermore, increasing the microsilica content enhances mullite formation and consequently the expansion of the matrix increases [24].

Effect of microsilica/cement ratio on the bulk density $(B D)$ and the apparent porosity $(A P)$

Fig. 2 shows the variation of bulk density with the microsilica content of the samples and it is seen that the 


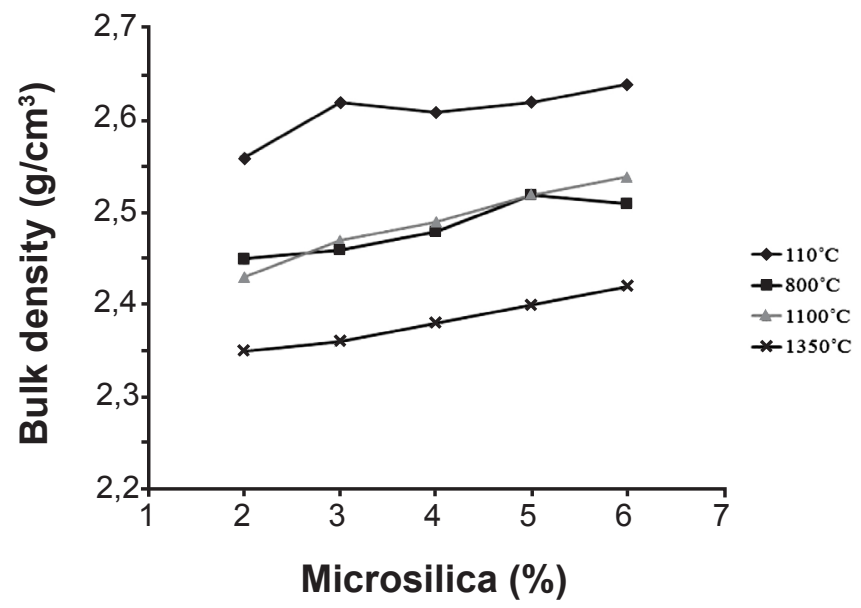

Figure 2: Effect of microsilica and cement content on bulk density (as microsilica content increases from 2 to $6 \mathrm{wt} . \%$, cement content decreases from 8 to $4 \mathrm{wt} . \%$ ).

[Figura 2: Efeito do teor de microsílica e de cimento na densidade aparente (com o aumento do teor de microsílica de 2 a 6 peso\%, o teor de cimento diminui de 8 para 4 peso\%).]

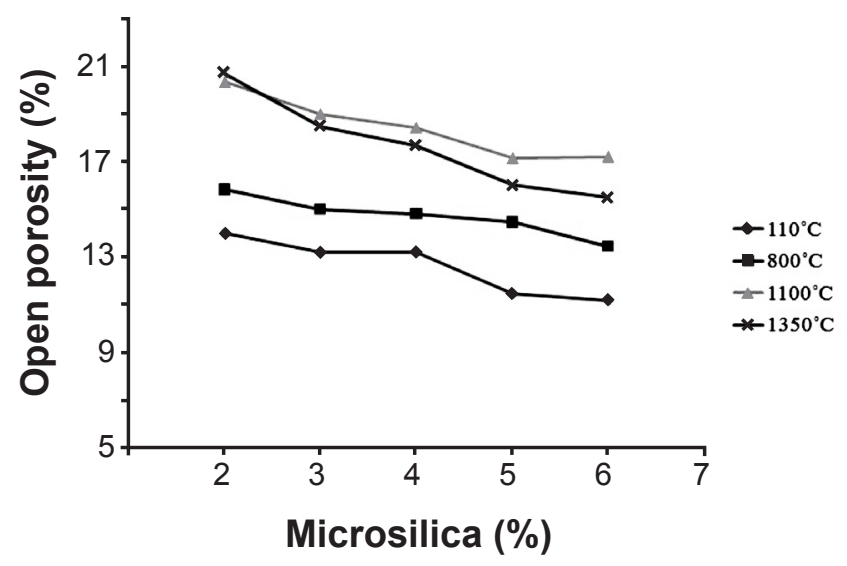

Figure 3: Effect of microsilica and cement content on open porosity (apparent porosity) (as microsilica content increases from 2 to 6 wt. $\%$, cement content decreases from 8 to $4 \mathrm{wt} . \%$ ).

[Figura 3: Efeito do teor de microsílica e de cimento na porosidade aberta (com o aumento do teor de microsílica de 2 a 6 peso\%, o teor de cimento diminui de 8 para 4 peso\%).]

increase in the microsilica content improves the bulk density. Fig. 3 illustrates the decrease in open porosities (O.P) by the increase of microsilica (MS), which clearly highlights the effectiveness of microsilica in densifying the material compared to refractory cement. Microsilica is used in low cement castables for its geometrical effects of filling small pores between the large aggregates, and also to enhance the sintering of the refractory matrix due to reaction with adjacent fine particles even at low temperatures which in turn improves the mechanical and physical properties [2]. Microsilica acts as filler at the drying temperature $\left(110{ }^{\circ} \mathrm{C}\right)$ and improves the flow properties of the castable along with decreasing the water required; at higher temperatures $\left(800{ }^{\circ} \mathrm{C}\right.$ and $\left.1100{ }^{\circ} \mathrm{C}\right)$, it decreases the pore volume and increases the bulk density of the bodies. The lowering of the density at $1350^{\circ} \mathrm{C}$ compared to the other three temperatures $\left(1100{ }^{\circ} \mathrm{C}, 800{ }^{\circ} \mathrm{C}\right.$ and $\left.110{ }^{\circ} \mathrm{C}\right)$ is attributed to the volume expansion due to mullite formation accompanied by grain growth of the mineral phases (about $10 \%$ for microsilica and alumina and for andalusite about $4-5 \%)$ [15]. Also, at elevated temperatures $\left(1350{ }^{\circ} \mathrm{C}\right)$, liquid phase sintering occurs resulting in the decrease in porosity and increase in the bulk density and this often results in the expansion effects in the material.

Effect of microsilica/cement ratio on the modulus of rupture (CMOR) and the cold crushing strength (CCS)

Fig. 4 and Fig. 5 present the effect of microsilica content on CCS and MOR values, respectively.

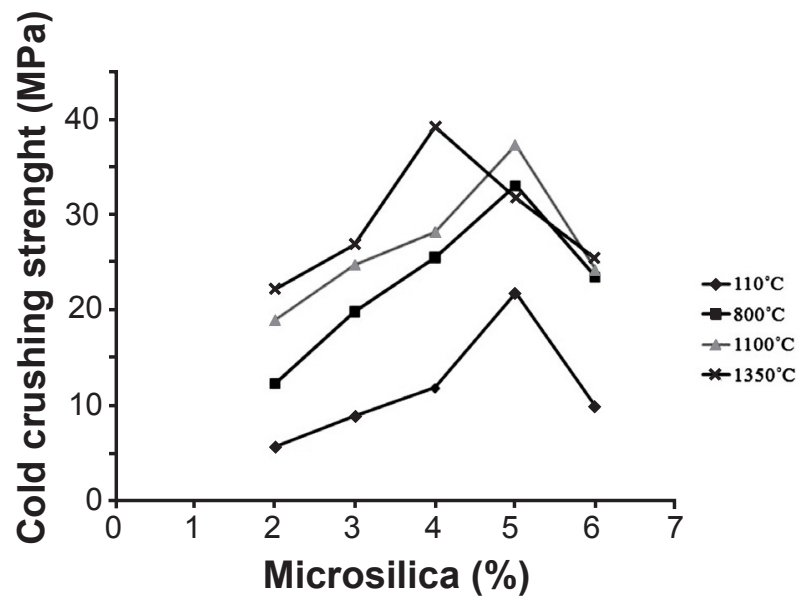

Figure 4: Effect of microsilica and cement content on cold compressive strength (as microsilica content increases from 2 to 6 wt.\%, cement content decreases from 8 to 4 wt.\%).

[Figura 4: Efeito do teor de microsílica e de cimento na resistência à compressão a frio (com o aumento do teor de microsílica de 2 a 6 peso $\%$, o teor de cimento diminui de 8 para 4 peso\%).]

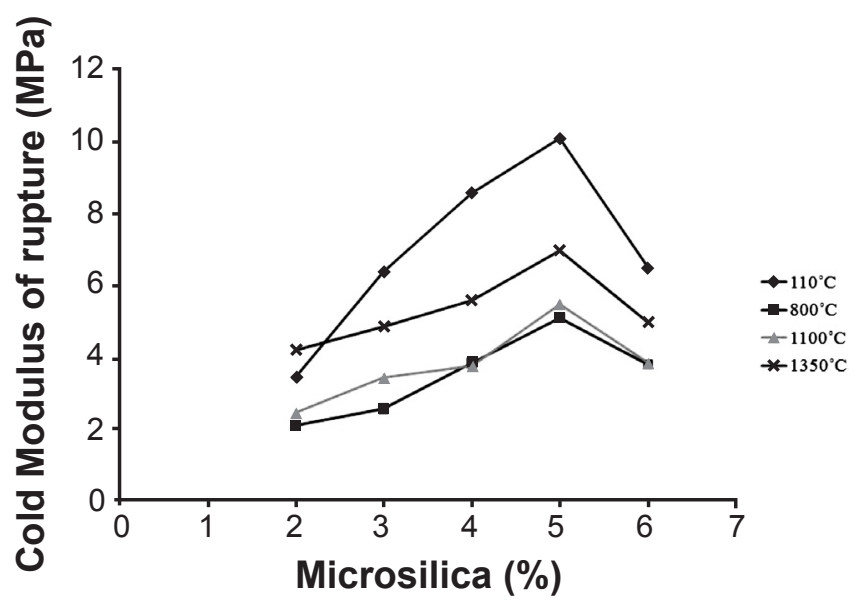

Figure 5: Effect of microsilica and cement content on cold modulus of rupture CMOR (as microsilica content increases from 2 to 6 wt.\%, cement content decreases from 8 to $4 \mathrm{wt} . \%$ ).

[Figura 5: Efeito do teor de microsílica e de cimento no módulo de ruptura (com o aumento do teor de microsílica de 2 a 6 peso\%, o teor de cimento diminui de 8 para 4 peso\%).] 
At $110{ }^{\circ} \mathrm{C}$, the green strength increases due to the formation of a thick gel between the microsilica and water. Myher et al [25] reported that when microsilica is mixed with water, some of the surface molecules will dissociate and enable a coagulation of microsilica particles. With time there will be a network of coagulated particles, forming a thickening gel. This gel formation gives improved green strength for castables with very low cement contents. Additionally, the gel structure assures strength during heatup by counteracting the strength degradation caused by dehydration of cement at temperatures between $200-800{ }^{\circ} \mathrm{C}$ $[25,26]$. At high temperatures, the strength improves because of the sintering process and the ability of the microsilica to react with alumina to form mullite [22]. The observed low strength of the bodies at low temperatures is due to lower grain strength and weaker bonding of the grains and matrix. Moreover, andalusite reactivity with the matrix increases with the beginning of the mullitization process at around $1300{ }^{\circ} \mathrm{C}$ and most of the bonding in the range of $1000{ }^{\circ} \mathrm{C}$ and $1200{ }^{\circ} \mathrm{C}$ is due to melting of impurities (such as $\mathrm{Fe}_{2} \mathrm{O}_{3}, \mathrm{TiO}_{2}, \mathrm{CaO}$ and $\mathrm{K}_{2} \mathrm{O}$ ) [18]. As observed from the results increasing the microsilica content up to $5 \mathrm{wt} . \%$ leads to an increase in CCS of Sample No. 4 while the CCS value decreases for sample No. 5 (sample 4 and sample 5 had 5 wt.\% and 6 wt. $\%$ microsilica, respectively). As mentioned in the previous section, decreasing the cement content reduces the apparent porosity of the body. The observed increasing strength of samples No. 1 to 4 is due to decreased pore volume percent which results from the increase in the microsilica content. However, there appears to be a limit to the extent of increase in the strength due to reduction in the cement content. It seems that the decrease in the cement content decreases the bonding strength between the particles and thereby decreases the mechanical strength of the material at lower temperatures, such as at $800{ }^{\circ} \mathrm{C}$, where loss of bonding occurs due to dehydration. Sample No. 4, contains more cement than sample No. 5, and hence has greater extent of hydrated bonding at $800{ }^{\circ} \mathrm{C}$ and thus shows higher values of strength. Some works have reported that with temperature and microsilica content increase in LCC and ULCC refractories, mullite formation (needle structure) increases significantly and it leads to an improvement of the strength at high temperatures [2530]. Also, the addition of andalusite and kyanite materials to LCC and ULCC refractories increases the refractory strength at high temperature [25].

In contradiction to the former, others have reported that in LCC refractories, due to low melting calcium aluminosilicate (CAS) phase formation (anorthite and gelenite), the high temperature strength values decreases severely $[7,31]$. In this study, at relative high temperatures $\left(1100{ }^{\circ} \mathrm{C}\right)$, anorthite formation was seen to increase bulk density thereby improving the bonding with increasing microsilica contents. But in sample No. 5 (sample containing 6 wt.\% microsilica and 4 wt.\% cement), the amount of anorthite formed is higher than in sample No. 4 (sample containing $5 \mathrm{wt} . \%$ microsilica and $5 \mathrm{wt} . \%$ cement) leading to a strength decrease in sample No. 5 . At $1350{ }^{\circ} \mathrm{C}$, mullite formation from andalusite transformation and reactions between silica and alumina enhances significantly with increase in the microsilica content. In the case of sample No. 5, the decrease in strength due to anorthite formation appears to have a stronger effect than the increase in strength due to mullite formation.

Effect of microsilicalcement ratio on the corrosion resistance with Al-alloy

In order to consider the effect of the pre-firing temperature on the corrosion resistance of refractories, 10 samples were pre-fired at $950{ }^{\circ} \mathrm{C}$ and 10 others at $1100{ }^{\circ} \mathrm{C}$. Fig. 6 shows the average penetration $(\mathrm{P})$ of molten $\mathrm{Al}$ into the refractory and the rating of corrosion resistance (ROCR). The rating used here is based on previously used standard method [32].

The results show that an increase in the pre-firing temperature does not dramatically affect the corrosion

\begin{tabular}{|l|c|c|}
\hline 1 & $\begin{array}{c}\mathrm{p} \\
(\mathrm{mm})\end{array}$ & 334 \\
\cline { 2 - 3 } & $\mathrm{ROCR}$ & 5 \\
\hline \multirow{4}{*}{2} & $\begin{array}{c}\mathrm{p} \\
(\mathrm{mm})\end{array}$ & 0.8 \\
\cline { 2 - 3 } & $\mathrm{ROCR}$ & 1 \\
\hline \multirow{2}{*}{3} & $\begin{array}{c}\mathrm{p} \\
(\mathrm{mm})\end{array}$ & 5.6 \\
\cline { 2 - 3 } & $\mathrm{ROCR}$ & 4 \\
\hline \multirow{4}{*}{4} & $\begin{array}{c}\mathrm{p} \\
(\mathrm{mm})\end{array}$ & 5.6 \\
\cline { 2 - 3 } & $\mathrm{ROCR}$ & 4 \\
\hline \multirow{2}{*}{5} & $\begin{array}{c}\mathrm{p} \\
(\mathrm{mm})\end{array}$ & 3.8 \\
\cline { 2 - 3 } & $\mathrm{ROCR}$ & 4 \\
\hline
\end{tabular}
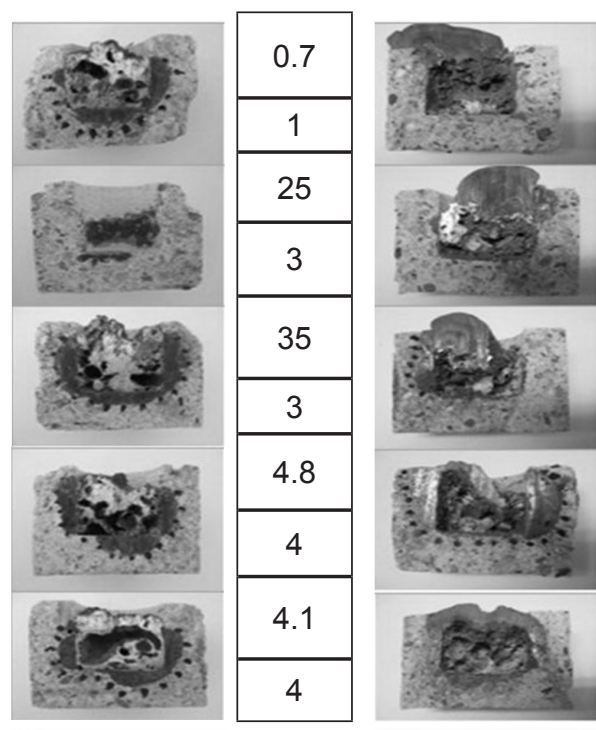

Figure 6: Varying corrosion resistance of the samples showing the different extents of alloy penetration. First column of pictures (left side): Pre-fired samples at $950{ }^{\circ} \mathrm{C}$ and tested at $850{ }^{\circ} \mathrm{C}$ for $150 \mathrm{~h}$. Second column of pictures (right side): Pre-fired samples at $1100{ }^{\circ} \mathrm{C}$ and tested at $1160{ }^{\circ} \mathrm{C}$ for $72 \mathrm{~h}$. P: Average Penetration of molten aluminum into refractory material ( $\mathrm{mm})$, ROCR: Rating of Corrosion Resistance of refractories, Number of samples shown at the left side of column ( $1=$ sample $1,2=$ sample 2 and so on). Rating 1 through 5 for corrosion resistance is relative rating shows the decrease in the corrosion resistance.

[Figura 6: Variação da resistência à corrosão de amostras mostrando os diferentes valores de penetração. Primeira coluna de fotos (lado esquerdo): Amostras pré-calcinadas a $950{ }^{\circ} \mathrm{C}$ e testadas a $850{ }^{\circ} \mathrm{C}$ durante $150 \mathrm{~h}$. Segunda coluna de fotos (lado direito): Amostras pré-calcinadas a $1100^{\circ} \mathrm{C}$ e testadas a $1160^{\circ} \mathrm{C}$ durante 72 h.P: Penetração média do alumínio fundido no material refratário (mm), ROCR: Taxa de resistência à corrosão dos refratários, Número das amostras mostradas no lado esquerdo da coluna (1=amostra 1, $2=$ amostra 2 , etc.). Classificação 1 até 5 para resistência à corrosão é a classificação relativa que mostra a diminuição na resistência à corrosão.] 
resistance of the samples. Generally, low microsilica content is associated with low penetration and high corrosion resistance. XRD, SEM (EDS) and optical microscopic investigations were used to analyze the data. The corrosion process in aluminosilicate refractories takes place via various mechanisms including infiltration by metal aluminum, alumino-thermit reactions and the formation of high temperature liquid phases, which are known to occur simultaneously [33]. Silica ( $\mathrm{SiO} 2)$ and mullite (3Al2O3.3SiO2), which are the two major components of the lining matrix, and silica-rich vitreous phases, are reduced to $\mathrm{Si}$, after reactions with molten aluminum or its alloys as shown by equations $\mathrm{C}$-E

$$
\begin{aligned}
& 4 \mathrm{Al}_{(\mathrm{L})}+3 \mathrm{SiO}_{2(\mathrm{~S})}=2 \mathrm{Al}_{2} \mathrm{O}_{3(\mathrm{~S})}+3 \mathrm{Si}_{(\mathrm{L})} \\
& \left(\Delta \mathrm{G}_{850^{\circ} \mathrm{C}}=-118.85 \mathrm{KJ} / \mathrm{mole} \mathrm{Al}\right) \\
& 8 \mathrm{Al}_{(\mathrm{L})}+3\left(3 \mathrm{Al}_{2} \mathrm{O}_{3} .2 \mathrm{SiO}_{2}\right)_{(\mathrm{S})}=13 \mathrm{Al}_{2} \mathrm{O}_{3(\mathrm{~S})}+6 \mathrm{Si}_{(\mathrm{L})} \\
& \left(\Delta \mathrm{G}_{850^{\circ} \mathrm{C}}=-118.58 \mathrm{KJ} / \mathrm{mole}\right) \\
& 2 \mathrm{Al}_{\mathrm{L})}+2 \mathrm{SiO}_{2(\mathrm{~S})}=\mathrm{Al}_{2} \mathrm{O}_{3(\mathrm{~S})}+\mathrm{Si}_{(\mathrm{L})}+\mathrm{SiO}_{(\mathrm{g})} \\
& \left(\Delta \mathrm{G}_{850^{\circ} \mathrm{C}}=-50.17 \mathrm{KJ} / \mathrm{mole} \mathrm{Al}\right)
\end{aligned}
$$

The interfaces of samples 2 and 3 are shown in Fig. 7 and they have been selected from the pre-fired and tested bodies at $950{ }^{\circ} \mathrm{C}$ and $850{ }^{\circ} \mathrm{C}$, respectively. It is quite clear that reaction between molten $\mathrm{Al}$ and refractory has resulted in increased pore formation in the reaction zone of sample No. 3 (sample containing $4 \mathrm{wt} . \%$ microsilica and $6 \mathrm{wt} . \%$ cement) compared to No. 2 (sample containing 3 wt.\% microsilica and $7 \mathrm{wt} . \%$ cement), while before the corrosion test, sample No. 2 was noted to have greater porosity than No. 3 (Fig. 3).

The increase in the porosity after the corrosion test could have occurred due to reaction 5 which produces $\mathrm{SiO}$ gas, or due to expansion associated with molten metal penetration and silica reduction in the refractory. The reduction of silica causes high volume shrinkage $(\sim 35 \%)$ which consequently leads to the propagation of cracks and increased penetration and corrosion by molten $\mathrm{Al}$ [34]. From the optical microscopy images, the reaction zone (RZ in Fig. 8) can be divided into 3 different regions: corroded area (metal-ceramic composite), unaffected ceramic (not in contact with molten $\mathrm{Al}$ ), and the reaction zone which is noted to be in front of the corroded area. In the corroded area, pores have been filled by molten aluminum but in the reaction zone pores are not filled. SEM and Optical microscopy images indicate that increasing the silica content produces glassy phase formation in the matrix and the interface. This low melting point glassy phase, located at the interface, accelerates the reaction rate and inter-granular corrosion [16]. This glassy phase contains high amounts of silica and alkaline oxides [35-37]. This microstructure is similar to those observed in previous studies $[33,35,36]$.

Fig. 9 shows the XRD patterns of the samples No.1 to 5 after firing at $1100{ }^{\circ} \mathrm{C}$ for $5 \mathrm{~h}$.

Andalusite, anorthite, corundum and Ba-celsian phases were observed to be present in the samples. From Fig. 9, it is clear that for samples No. 1 to 5 , the relative peak intensities of Ba-celsian increased while that for anorthite remained fixed. On the other hand, it can be seen that peak broadening has taken place in samples containing more microsilica, especially sample 5. The peak broadening could be attributed to glass formation in ceramics and refractories. Therefore, two main factors were noted to affect the corrosion resistance of the samples and these are discussed in the next section.

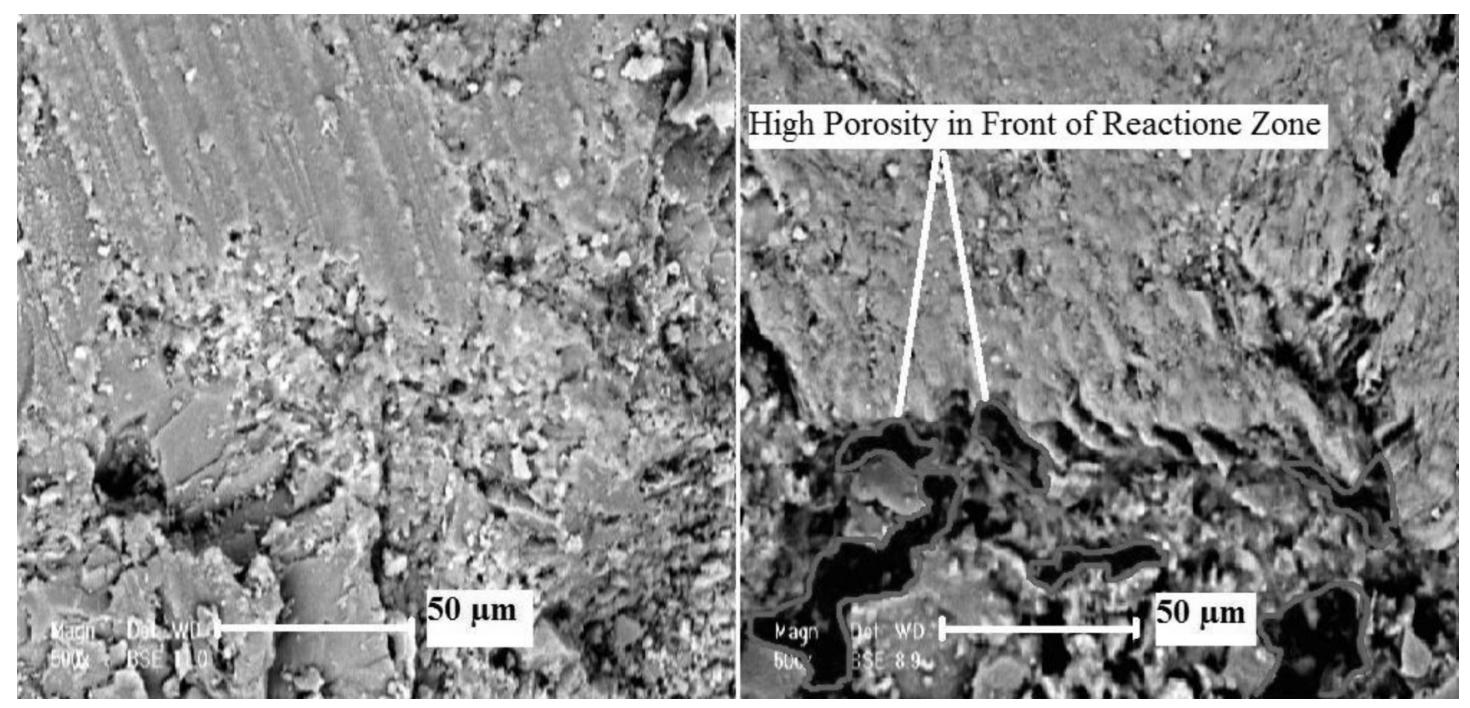

Figure 7: SEM images show the in Front of Reaction Zone No. 2 (left) and sample No. 3 (right). Comparing the reaction zones (or interfacial layer) for samples 2 and samples 3, it is clear that the porosity in the reaction zone of sample 3 is higher.

[Figura 7: Imagens de microscopia eletrônica de varredura mostram a Zona N. 2 - Frente de reação (esquerda) $e$ amostra No. 3 (direita). Comparando as zonas de reação (ou camadas interfaciais) para amostras 2 e 3, fica claro que é maior a porosidade na zona de reação da amostra 3.] 


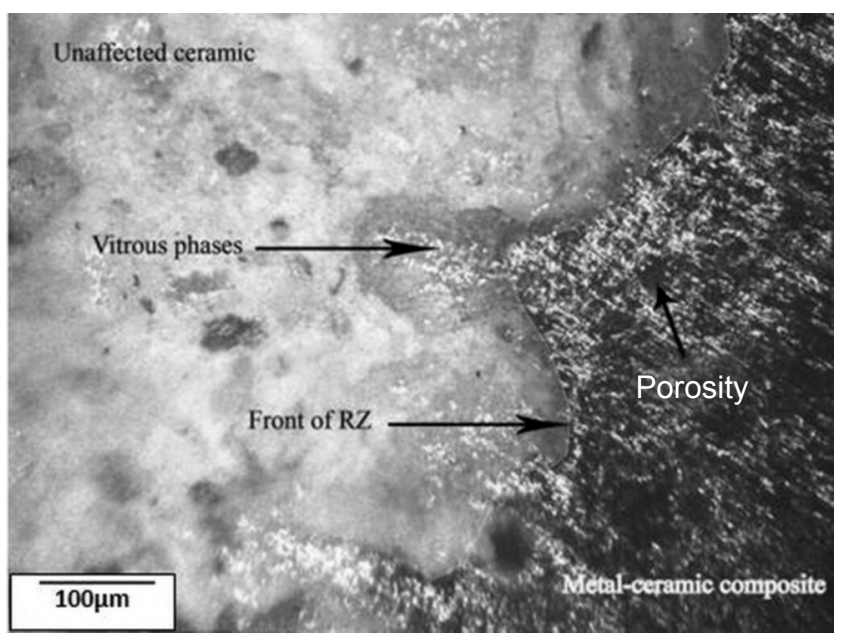

Figure 8: Optical Microscopy micrograph of reaction zone (RZ) in body No. 3 showing 3 regions. Corroded area (right), not reacted (left) and interface (between).

[Figura 8: Micrografia de microscopia óptica da zona de reação (RZ) na amostra 3 mostrando 3 regiões. Área corroída (direita), não reagida (esquerda) e interface (no meio).]

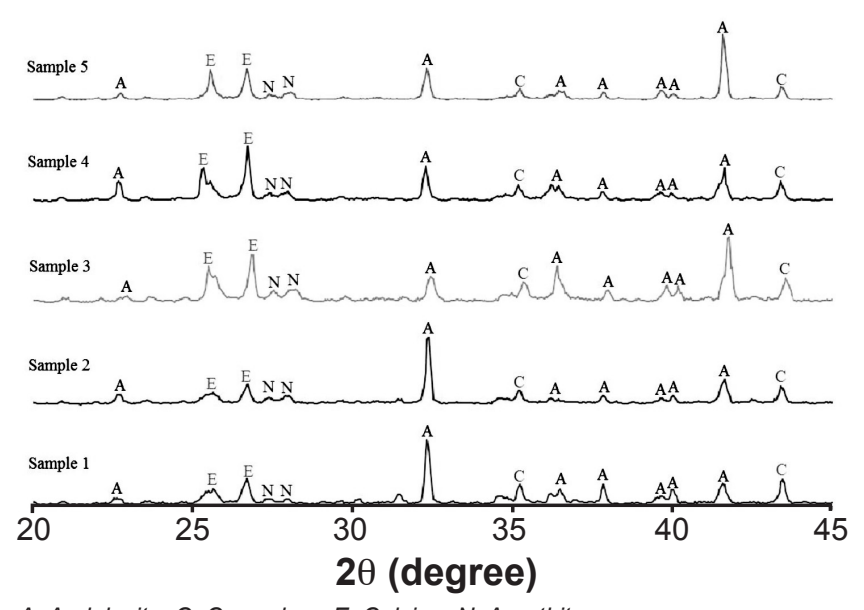

A: Andalusite; C: Corundum; E: Celsian; N: Anorthite

Figure 9: XRD patterns of different refractory samples heated at $1100{ }^{\circ} \mathrm{C}$ for $5 \mathrm{~h}$ (numbers on the right represents the sample numbers) (JCPDS files - Andalusite: 13-0122; Corundum: 431484; Celsian: 19-0090; Anorthite: 20-0020).

[Figura 9: Difratogramas de raios $X$ de diferentes amostras de refratários calcinadas a $1100{ }^{\circ} \mathrm{C}$ durante $5 \mathrm{~h}$ (números na direita representam os números das amostras) (arquivos JCPDS - Andalusita: 13-0122; Corundum: 43-1484; Celsian: 19-0090; Anortita: 20-0020)]

Effect of formation of anorthite phase on the corrosion resistance: The formation of anorthite occurs due to reactions between microsilica and the calcium cement phases in the refractory and its presence can increase the corrosion resistance of aluminosilicate refractories in contact with Alalloys [17, 21, 38]. However with the decrease in the cement content, it can be seen that the relative peak intensity of anorthite has not changed significantly (Fig. 9), even though the presence of cement is believed to be linked strongly to the anorthite and gehlenite contents [3, 4].
Effect of the formation of Ba-celsian phase on the corrosion resistance of bodies: As mentioned before, Ba-celsian phase was observed in all the samples but the amount was higher in those samples with high microsilica content. Barite, by reacting with alumina and free silica in the refractory, forms Ba-celsian in the firing temperature ranging between $900-1200{ }^{\circ} \mathrm{C}$. Such transformation reduces the amount of free silica within the matrix and consequently, improves the corrosion resistance [17, 21, 39]. Since there are no other sources of silica in the refractory, silica originates from microsilica. Because of the low microsilica content of sample Nos. 1 and 2, formation of Ba-celsian was insufficient but it was significant in samples with high microsilica content. It seems that formation of more $\mathrm{Ba}$ celsian phase in samples with high microsilica did not result in an increase in the corrosion resistance. Fig. 8 shows the optical microscopy image of the interface of sample No. 3. Glassy phase formation is seen in the matrix and at the refractory/metal interface. Therefore it can be concluded that increasing the microsilica content, in addition to more Ba-celsian formation, will lead to the formation of higher amounts of glassy phases (barium silicates) as well and free silica content which decreases the corrosion resistance.

In this study, increase in the cement is accompanied by the subsequent decrease in the microsilica content. In this condition (prefiring temperature: $1100{ }^{\circ} \mathrm{C}$ ) andalusite does not transform to mullite and silica; thereby anorthite forms from the reaction between microsilica and cement phases. However, it is observed that the formation of Ba-celsian is enhanced with the increasing microsilica content. It seems that the tendency is greater for the reaction between microsilica and barite (or $\mathrm{BaO}$ resulting of decomposition of barite) rather than microsilica and cement phases. Santillan [40] reported that barite decomposes at $1150{ }^{\circ} \mathrm{C}$ to produces fresh $\mathrm{BaO}$ in the matrix of the refractory. Since barite decomposes partially at $1150{ }^{\circ} \mathrm{C}$, the resulting $\mathrm{BaO}$ is more reactive rather than calcium aluminate phases. This is in contradiction to other works which state that barite decomposes only at higher temperatures $\left(\sim 1550{ }^{\circ} \mathrm{C}\right)[41$, 42].

$$
\begin{aligned}
& \mathrm{BaO}_{(\mathrm{S})}+\mathrm{Al}_{2} \mathrm{O}_{3(\mathrm{~S})}+\mathrm{SiO}_{2(\mathrm{~S})}=\mathrm{BaAl}_{2} \mathrm{Si}_{2} \mathrm{O}_{8(\mathrm{~S})} \\
& \left(\Delta \mathrm{G}_{1100^{\circ} \mathrm{C}}=-227.069 \mathrm{KJ}\right) \\
& \mathrm{CaAl}_{2} \mathrm{O}_{4(\mathrm{~S})}+2 \mathrm{SiO}_{2(\mathrm{~S})}=\mathrm{CaAl}_{2} \mathrm{Si}_{2} \mathrm{O}_{8(\mathrm{~S})} \\
& \left(\Delta \mathrm{G}_{1100^{\circ} \mathrm{C}}=-88.988 \mathrm{KJ}\right)
\end{aligned}
$$

Therefore two routes for the formation of celsian could be mentioned. In the first state, it can be considered that barite decomposes to $\mathrm{BaO}$ at the heat treatment temperature. Comparison of the calculated Gibbs free energy of reactions between $\mathrm{BaO}$ (resulting from the decomposition of barite) and silica and alumina and between cement phases and silica shows that former reaction is thermodynamically more feasible (Equations $\mathrm{F}$ and $\mathrm{G}$ respectively):

Therefore, this information shows that thermodynamically and kinetically (due to the formation of a fresh 
reactive surface of barium oxide), the reaction between silica, alumina and barium phases occurs more readily than the reactions between silica and calcium phases. This is validated from the XRD results (Fig. 9) which show that with increasing microsilica content, Ba-celsian forms more easily than Ca-anorthite.

Equations $\mathrm{H}-\mathrm{K}$ show the reactions between barium sulphate and alumina, silica and of the decomposition of barium sulphate, while Fig. 10 shows the variation of the calculated standard Gibbs free energy of these reactions in range of $800-1400{ }^{\circ} \mathrm{C}$. These thermodynamic data imply that barium sulphate does not decompose in temperature range between $800-1400{ }^{\circ} \mathrm{C}$ as stated in other works [ 41 , 42]. However, it is clear from the XRD patterns and EDS analysis of sample 2 (Fig. 11) that no barium sulphate or sulfur containing species were present in the refractory matrix. Also, from Fig. 10, it is seen that by adding alumina and silica to barium sulphate at $1130{ }^{\circ} \mathrm{C}$, the Gibbs free energy of the reaction related to the formation of celsian becomes negative indicating that celsian formation is possible under this condition (Fig. 11).

$$
\begin{aligned}
& 2 \mathrm{BaSO}_{4(\mathrm{~S})}+4 \mathrm{SiO}_{2(\mathrm{~S})}+2 \mathrm{Al}_{2} \mathrm{O}_{3(\mathrm{~S})}=2 \mathrm{BaAl}_{2} \mathrm{Si}_{2} \mathrm{O}_{8(\mathrm{~S})}+ \\
& 2 \mathrm{SO}_{2(\mathrm{~g})}+\mathrm{O}_{2(\mathrm{~g})} \\
& 2 \mathrm{BaSO}_{4(\mathrm{~S})}+2 \mathrm{SiO}_{2(\mathrm{~S})}=2 \mathrm{BaSiO}_{3(\mathrm{~S})}+2 \mathrm{SO}_{2(\mathrm{~g})}+\mathrm{O}_{2(\mathrm{~g})} \\
& 2 \mathrm{BaSO}_{4(\mathrm{~S})}+2 \mathrm{Al}_{2} \mathrm{O}_{3(\mathrm{~S})}=2 \mathrm{BaAl}_{2} \mathrm{O}_{4(\mathrm{~S})}+2 \mathrm{SO}_{2(\mathrm{~g})}+\mathrm{O}_{2(\mathrm{~g})} \\
& 2 \mathrm{BaSO}_{4(\mathrm{~S})}=2 \mathrm{BaO}_{(\mathrm{S})}+2 \mathrm{SO}_{2(\mathrm{~g})}+\mathrm{O}_{2(\mathrm{~g})}
\end{aligned}
$$

From the analysis of the observations, it can be concluded that celsian formation occurs in the refractory from the decomposition of barite at the heat treatment temperatures.

The interface of samples 2 and 3 were further characterized using XRD analysis and the results are shown in Fig. 12. (These samples were tested at $850{ }^{\circ} \mathrm{C}$ for $150 \mathrm{~h}$ ). The figure shows that andalusite and corundum are present after the corrosion test in the both samples as the dominant phases. With regard to Fig. 9, it is clear that corundum is present as a minor phase, but after the corrosion test (Fig. 12), it becomes the dominant phase. Also barium celsian, aluminum, calcium, barium and silicon are present in lower contents in both samples. Moreover, the results show that anorthite is not present in both the samples, even though it was observed to be present in the unreacted region from Fig. 11. Fig. 12 also shows that the relative peak intensity of celsian is higher in sample 2 than 3.The Gibbs free energy of reaction between anorthite and aluminium-alloy shows that it is reduced thermodynamically by molten aluminum or alloying elements such as $\mathrm{Mg}$ (Equations $\mathrm{L}$ and $\mathrm{M}$ ):

$$
\begin{aligned}
& \mathrm{CaAl}_{2} \mathrm{Si}_{2} \mathrm{O}_{8(\mathrm{~S})}+3.333 \mathrm{Al}_{(\mathrm{L})}=\mathrm{Ca}_{(\mathrm{L})}+2 \mathrm{Si}_{(\mathrm{L})}+ \\
& 2.667 \mathrm{Al}_{2} \mathrm{O}_{3(\mathrm{~S})}\left(\Delta \mathrm{G}_{850^{\circ} \mathrm{C}}=-132.20 \mathrm{KJ}\right)
\end{aligned}
$$

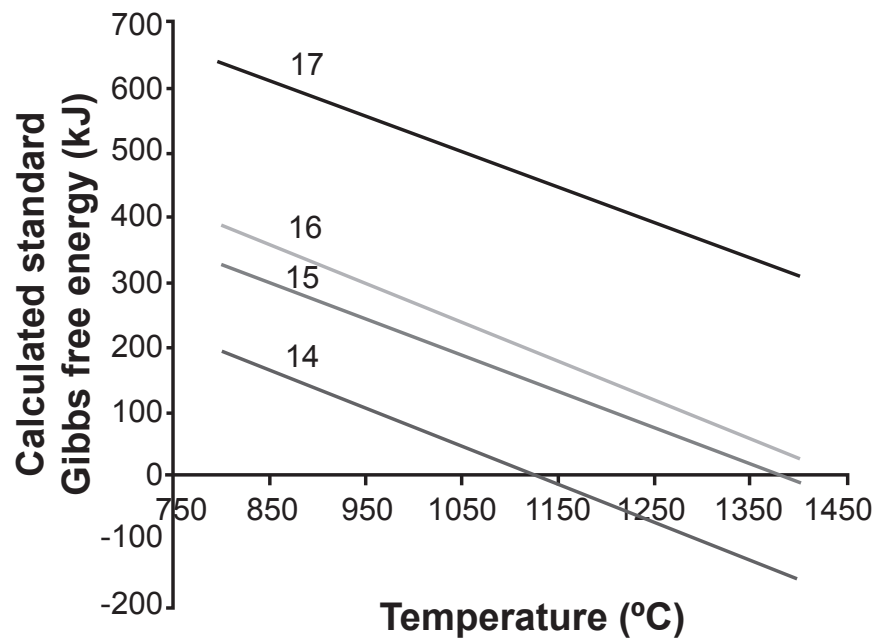

Figure 10: Calculated standard Gibbs free energy for reactions L-OP.

[Figura 10: Energia livre padrão de Gibbs para as reações L-OP.]

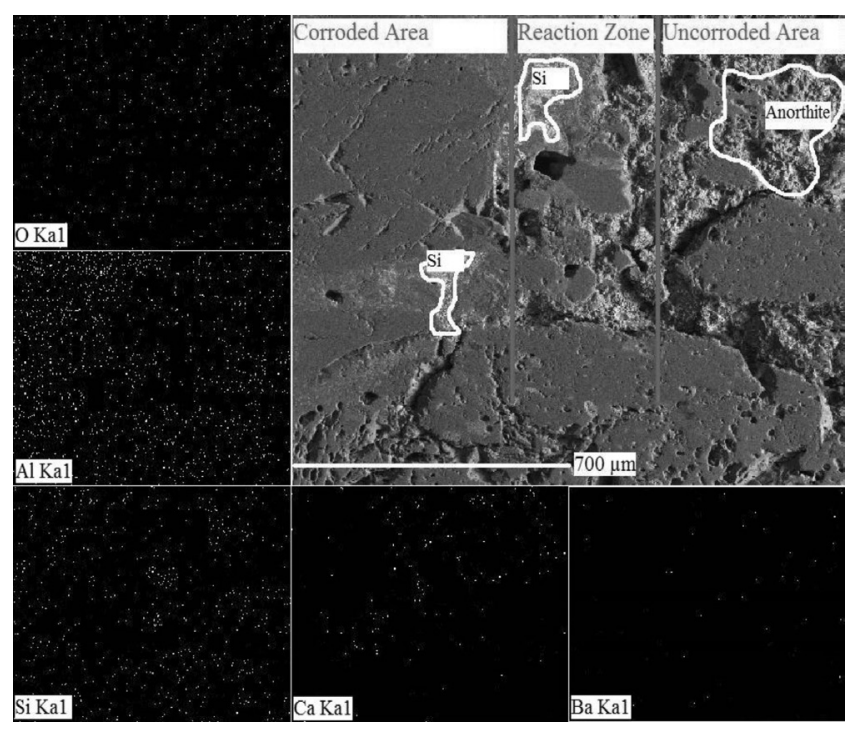

Figure 11: X-ray mapping of the interfacial layer of sample 2 (containing 3 wt.\% microsilica and $7 \mathrm{wt} . \%$ cement). This sample contained $\mathrm{BaSO}_{4}$ as an additive and was tested at $850^{\circ} \mathrm{C}$ for $150 \mathrm{~h}$. [Figura 11: Imagens de raios $X$ da camada interfacial da amostra 2 (contendo 3 peso $\%$ de microsílica e 7 peso\% de cimento). Esta amostra continha $\mathrm{BaSO}_{4}$ como aditivo e foi testada a $850{ }^{\circ} \mathrm{C}$ durante $150 \mathrm{~h}$.

$\mathrm{CaAl}_{2} \mathrm{Si}_{2} \mathrm{O}_{8(\mathrm{~S})}+8 \mathrm{Mg}_{(\mathrm{L})}=\mathrm{Ca}_{(\mathrm{L})}+2 \mathrm{Si}_{(\mathrm{L})}+8 \mathrm{MgO}_{(\mathrm{S})}$ $+2 \mathrm{Al}_{(\mathrm{L})}\left(\Delta \mathrm{G}_{850^{\circ} \mathrm{C}}=-441.36 \mathrm{KJ}\right)$

Figs. 11 and 13 show the X-ray mapping of the interfacial layer and corroded area of sample 2, respectively. In both figures, presence of $\mathrm{Ca}$ is clear in the corroded area of this sample. Furthermore, XRD patterns and EDS results (Figs. 11-13) show that $\mathrm{Ba}$ is present in the corroded area of sample 2 , even though Ba-celsian is also present as seen from the XRD pattern of two samples (Fig. 12). Calculated Gibbs free energy for reaction between $\mathrm{Ba}-$ celsian phase and molten $\mathrm{Al}$ and $\mathrm{Mg}$ is shown by equations 15 and 16 respectively: 
$\mathrm{BaAl}_{2} \mathrm{Si}_{2} \mathrm{O}_{8(\mathrm{~S})}+3.333 \mathrm{Al}_{(\mathrm{L})}=\mathrm{Ba}_{(\mathrm{L})}+2 \mathrm{Si}_{(\mathrm{L})}+$

$2.667 \mathrm{Al}_{2} \mathrm{O}_{3(\mathrm{~S})}\left(\Delta \mathrm{G}_{850^{\circ} \mathrm{C}}=-114.73 \mathrm{KJ}\right)$

$\mathrm{BaAl}_{2} \mathrm{Si}_{2} \mathrm{O}_{8(\mathrm{~S})}+8 \mathrm{Mg}_{(\mathrm{L})}=\mathrm{Ba}_{(\mathrm{L})}+2 \mathrm{Si}_{(\mathrm{L})}+8 \mathrm{MgO}_{(\mathrm{S})}+$

$2 \mathrm{Al}_{(\mathrm{L})}\left(\Delta \mathrm{G}_{850^{\circ} \mathrm{C}}=-423.90 \mathrm{KJ}\right)$

By comparing the Gibbs free energy values of the reactions of $\mathrm{Ca}$-anorthite and $\mathrm{Ba}$-anorthite by the alloy, it is clear that the reaction between $\mathrm{Ca}$-anorthite and molten $\mathrm{Al}$ and also alloying element is done very easy thermodynamically. Also XRD results (Fig. 12) imply that Ba-anorthite is more stable than Ca-anorthite in contact
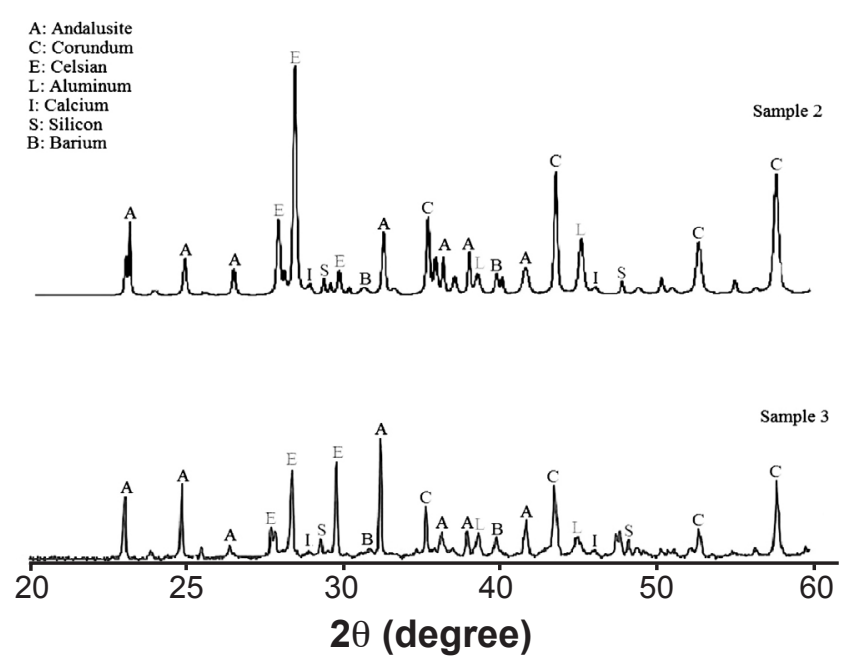

Figure 12: XRD patterns of samples 2 and 3 that were tested at $850{ }^{\circ} \mathrm{C}$ for $150 \mathrm{~h}$. (JCPDS files - Aluminum: 01-1180; Silicon: 26-1481; Barium: 49-1481; Calcium: 01-0737, other JCPDS files are present in Fig. 9).

[Figura 12: Difratogramas de raios $X$ das amostras 2 e 3 que foram testadas a $850{ }^{\circ} \mathrm{C}$ durante $150 \mathrm{~h}$. (arquivos JCPDS - Alumínio: 011180; Silício: 26-1481; Bário: 49-1481; Cálcio: 01-0737, outros arquivos JCPDS estão na Fig. 9).]

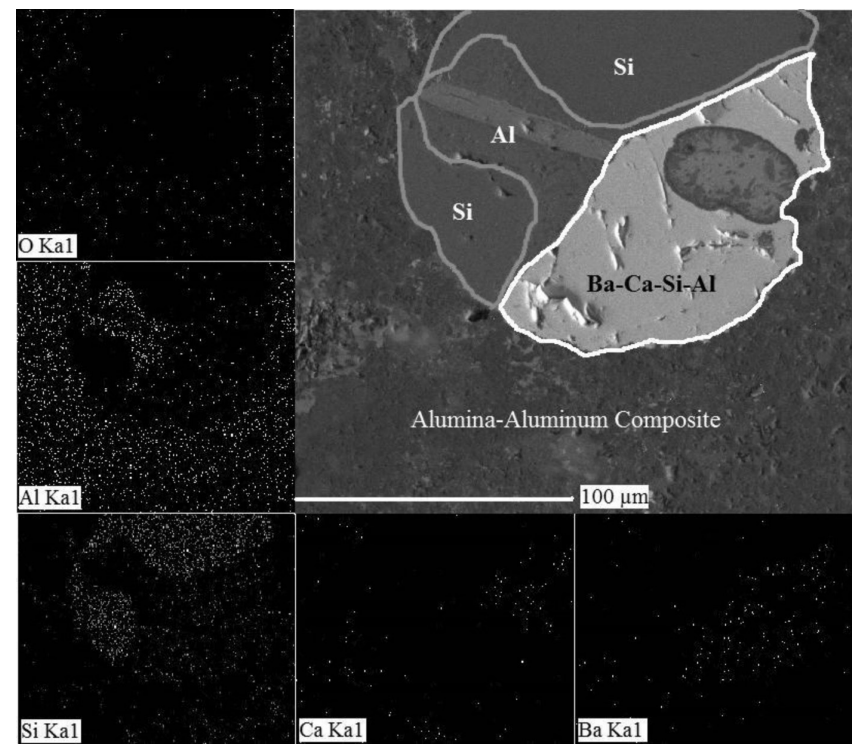

Figure 13: X-ray mapping of the corroded area of sample 2.

[Figura 13: Mapeamento de raios X da área corroída da amostra 2.] with molten Al. However these two phases can be reduced by molten $\mathrm{Al}$ resulting in the formation of intermetallic containing $\mathrm{Ba}, \mathrm{Ca}$ and $\mathrm{Si}$ in the corroded area (Fig. 13). Fig. 13 shows that these elements are accumulated in spots along with Al. In general, corroded area of this sample contained the alumina-aluminum composite along with spots rich in $\mathrm{Si}$ and having lower contents of $\mathrm{Ca}-\mathrm{Ba}$.

\section{CONCLUSIONS}

The study investigated the effect of microsilica and refractory cement content on the properties of andalusite based LCCs used in aluminum casthouse. The major findings are as follows:

Increase in the microsilica content improves the physical properties (increase in bulk density and decrease in Open Porosity) and mechanical properties (increase in Cold Modules and Crushing Strenght) of andalusite low cement castables. However, the increase in the microsilica content drastically decreases the corrosion resistance. Presence of higher microsilica in andalusite LCC refractory results in the formation of low melting point liquids and glassy phases which accelerate the corrosion. Therefore, the adequate microsilica content is determined to be lower than $3 \%$. Alumino-thermit reactions and production of $\mathrm{SiO}$ gas through reactions could result in increased pore formation in the refractory samples which aids in providing pathways for metal penetration and increased corrosion. With increase in the microsilica content (decrease in cement) Ba-celsian and glassy phase formations are enhanced. The positive effect of Ba-celsian on corrosion resistance is reduced by the formation of glassy phase. Anorthite phase formation was also observed to increase the corrosion resistance. Calculation of the gibbs free energy values indicate that $\mathrm{Ba}-$ anorthite is more stable than $\mathrm{Ca}$-anorthite in contact with molten $\mathrm{Al}$ and alloying elements.

\section{ACKNOWLEDGEMENTS}

The authors acknowledge Amol Refractory Industrial Company for financial \& technical supports.

\section{REFERENCES}

[1] K. T. Raić, T. Volkov-Husović, R. Jančić, Metalurgija Mjom. 10, 1 (2004) 37-50.

[2] S. Gupta, P. Koshy, V. Sahajwalla M. Pauline, N. Leicht, in UNITECR'05 Proc, Orlando, FL, ACS, Westeville, OH (2005) pp. 630-634.

[3] B. Myhre, B. Sandberg, Proc. $1^{\text {st }}$ Int. Conf. Monolithic, Tehran, Iran (1997) pp. 113-140.

[4] C. Parr, T. A. Bier, N. E. Bunt, E. Spreafico, Proc. $1^{\text {st }}$ Int. Conf. Monolithic, Tehran, Iran (1997) pp. 141-152.

[5] F. Simonin, C. Olagnon, S. Maximilien, G. Fantozzi, L. Diaz, R. Torrecillas, J. Am. Ceram. Soc. 83, 10 (2000) 24812490

[6] O.-j. Siljan, G. Rain, D. T. Petterson, A. Solheim, C. 
Schoning, J. Refr. Appl. News. 7, 6 (2002) 17-25.

[7] H. Sarpoolaky, K. Ahari, W. Lee, Ceram. Int. 28 (2002) 487-493.

[8] T. Tonnesen, R. Telle, $9^{\text {th }}$ Biennial Worldwide Cong. Refractories, UNITECR '05,Proc. Unif. Int. Techn. Conf. Refractories, Orlando Florida, ACS (2005) pp.642-646.

[9] D. Daspoddar, S. K. Das, P. K. Daspoddar, Bull. Mater. Sci. 26, 2 (2003) 227-231.

[10] P. Koshy, Ph. D. Thesis, Un. New South Wales, Australia (2009).

[11] G. Buchel, A. Buhr, D. Gierisch, R. P. Racher, $48^{\text {th }}$ Int. Feuerfest-Kolloquium, Aachen, Germany (2005) pp. 208214.

[12] K. Santowski, K. Gamweger, B. Schmalenbach, T. Weichert, UNITECR'07, Dresden, Germany, The German Refractories Association (GRA), Dresden, Germany (2007) pp. 250-253.

[13] B. Myhre, UNITECR' 05 Proc. Unif. Int. Techn. Conf. Refractories, $9^{\text {th }}$ Biennial Worldwide Cong. Refractories, (2005) pp.191-195.

[14] R. Studart, V. C. Pandolfelli, Am. Ceram. Soc. Bull. 79, 10 (2000) 53-60.

[15] Z. Minghua, M.Sc. Diss., École Polytechnique Montreal, Canada (2004).

[16] S. Afshar, C. Gaubert, C. Allaire, JOM 55, 11 (2003) 66-69.

[17] S. Afshar, C. Allaire, JOM 53, 8 (2001) 24-27.

[18] J. Goicoechea, C. Garcia-Cordovilla, E. Louis, A. Pamies, J. Mater. Sci. 27, 19 (1992) 5247-5252.

[19] M. E. Perron, C. Allaire, J. Can. Ceram. Soc. 69, 2 (2000) 31-35.

[20] M. Allahverdi, S. Afshar, C. Allaire, JOM 50, 2 (1998) 30-34.

[21] P. Hubert, Tehran Int. Conf. Refractories (2004) pp. 434-443.

[22] R. Hagen, C. Lamy, B. Myhre, H. Peng, UNITECR'09, Salvador, Brazil (2009).

[23] L. Rebouillat, M. Rigaud, J. Am. Ceram. Soc. 85, 2 (2002) 373-378.

[24] B. Myhre, J. Refr. Appl. News. 13, 6 (2008) 11-19.

[25] B. Sandberg, B. Myhre, Elkem Materiels, Norway,
Indian Refractories Cong., Jamshedpur, India (1994).

[26] B. Myhre, Elkem Materiels, Norway, American Ceramic Society $95^{\text {th }}$ Annual Meeting Cincinnati, Ohio, USA (1993).

[27] B. Myhre, A. M. Hundere, H. Feldborg, C. Ødegård, Proc. VIII Int. Met. Conf. Ustron, Poland (1999) pp. 163172.

[28] S. H. Risbud, J. A. Pask, J. Mater. Sci. 13, 11 (1978) 2449-2454.

[29] M. F. M. Zawrah, N. M. Khalil, Ceram. Int. 27, 6 (2001) 689-694.

[30] N. Montoya, F. J. Serrano, M. M. Reventós, J. M. Amigo, J. Alarcón, J. Eur. Ceram. Soc. 30, 4 (2010) 839846.

[31] E. Nonnet, N. Lequeux, P. Boch, J. Eur. Ceram. Soc. 19 (1999) 1575-1583.

[32] S. Quesnel, C. Allaire, S. Afshar, Light Metals, Addendum Section, Proc. TMS (1998) pp. 1391-1402.

[33] C. Emilio, M. Rafael, UNITECR'99, Berlin, Germany (1999) pp. 376-379.

[34] M. Franken, P. van Berkel, UNITECR'07, Dresden, Germany (2007) pp. 424-427.

[35] M. Oliveira, S. Agathopoulos, J. M. F. Ferreira, J. Mater. Res. 17, 3 (2002) 641-647.

[36] M. Oliveira, S. Agathopoulos, J. Lino, J. M. F. Ferreira, Mater. Sci. Forum. 455-456 (2004) 39-643.

[37] M. Oliveira, S. Agathopoulos, J. M. F. Ferreira, Acta Mater. 50, 6 (2002) 1441-1451.

[38] P. Koshy, S. Gupta, V. Sahajwalla, P. Edwarss, Metall. Mater. Trans. B. 39, 4 (2008) 603-612.

[39] D. Shukla, J. D. Smith, J. Refr. Appl. Trans. 4, 3 (2009) 2-8.

[40]J.A.Santillan, J.Nanomater.DOI: 10.1155/2008/629185 (2008) 1-12.

[41] J. DeMent, The Element and Inorganic Compounds, Handbook of Chemistry and Physics, $55^{\text {th }}$ Ed., Ed. R. C. Weast, CRC Press, Cleveland, OH, USA, 44128 (19741975) B63-B156.

[42] H. J. Schmutzler, K. H. Sandhage, Metall. Mater. Trans. B. 26, 1 (1995) 135-148.

[43] D. Shukla, J. Refr. Appl. News. 12, 6 (2007) 23-16.

(Rec.09/08/2010, Ac.02/10/2010) 